NBER WORKING PAPER SERIES

\title{
THE DETERMINANTS OF PROGRESSIVE ERA REFORM: THE PURE FOOD AND DRUGS ACT OF 1906
}

\author{
Marc T. Law \\ Gary D. Libecap \\ Working Paper 10984 \\ http://www.nber.org/papers/w10984 \\ NATIONAL BUREAU OF ECONOMIC RESEARCH \\ 1050 Massachusetts Avenue \\ Cambridge, MA 02138 \\ December 2004
}

The views expressed herein are those of the author(s) and do not necessarily reflect the views of the National Bureau of Economic Research.

(C) 2004 by Marc T. Law and Gary D. Libecap. All rights reserved. Short sections of text, not to exceed two paragraphs, may be quoted without explicit permission provided that full credit, including $\odot$ notice, is given to the source. 
The Determinants of Progressive Era Reform: The Pure Food and Drugs Act of 1906

Marc T. Law and Gary D. Libecap

NBER Working Paper No. 10984

December 2004

JEL No. I1, N4, L5

\title{
ABSTRACT
}

We examine three theories of Progressive Era regulation: public interest, industry capture, and information manipulation by the federal bureaucracy and muckraking press. Based on analysis of qualitative legislative histories and econometric evidence, we argue that the adoption of the 1906 Pure Food and Drugs Act was due to all three factors. Select producer groups sought regulation to tilt the competitive playing field to their advantage. Progressive reform interests desired regulation to reduce uncertainty about food and drug quality. Additionally, rent-seeking by the muckraking press and its bureaucratic allies played a key role in the timing of the legislation. We also find that because the interests behind regulation could not shape the enforcing agency or the legal environment in which enforcement took place, these groups did not ultimately benefit from regulation in the ways originally anticipated.

\author{
Marc T. Law \\ Department of Economics \\ University of Vermont \\ Old Mill Building \\ 94 University Place \\ Burlington, VT 05405-0114 \\ marc.law@uvm.edu \\ Gary D. Libecap \\ Department of Economics \\ University of Arizona \\ Tucson, AZ 85721-0108 \\ and NBER \\ glibecap@eller.arizona.edu
}




\section{Introduction ${ }^{1}$}

The late nineteenth and early twentieth centuries witnessed the birth of the American regulatory state. During the Progressive Era, federal authority over banking, insurance, transportation, competition, and interstate trade in food and drug products greatly expanded. Indeed, it is during this period that the federal government began to displace state and local governments as the primary source of regulation in the economy. Government regulation not only became more federal, but more intrusive. The question is why.

Broadly speaking, there are three views of the emergence of the federal regulatory state. One is a public interest view that argues that federal regulation arose to solve market failures that state and local governments could not address, and that Progressive Era reformers interested in improving consumer welfare lobbied in favor of these regulations. While this account is supported by a large historical literature, it fails to explain why regulation, as opposed to the court system, was needed to safeguard consumer welfare (Glaeser and Schleifer 2003). A second view is that regulation was adopted to give a competitive advantage to business groups. This regulatory capture argument is intuitively appealing, but it cannot account for why there was so much contemporaneous popular support for regulation. A third view emphasizes the role played by the muckraking press and entrepreneurial bureaucrats in galvanizing public support for regulation. The exact mechanisms by which these interests influenced the adoption of

\footnotetext{
${ }^{1}$ We thank Dan Carpenter, Ed Glaeser, Claudia Goldin, and participants of the NBER Corruption and Reform Conference for their helpful comments. Tomas Nonenmacher and Lee Alston graciously provided data on reform interest groups.
} 
regulation, however, have not been explored. While the first view emphasizes the efficiency-improving role of regulation, the latter two suggest that regulation may have had dubious effects on consumer welfare.

In this chapter, we examine these three explanations for the adoption of Progressive Era regulation through the lens of federal food and drugs legislation. In 1906 the federal government enacted the Pure Food and Drugs Act, the first federal law that gave regulators unprecedented authority over interstate trade in food and drug products. The central issues we investigate are the timing and nature of support for the food and drugs act. We also explore the early enforcement of this law and its effects on consumer welfare. The passage of this act can reveal much about the entire Progressive agenda and the establishment of the Food and Drug Administration (FDA). ${ }^{2}$

We find that aspects of all three views of regulation explain the adoption of the Pure Food and Drugs Act, that producer, consumer, and bureaucratic interests maneuvered to mold the law to their benefit, and that the muckraking press influenced the timing of adoption. Both the legislative history and statistical analysis underscore the desires of various producer groups to tilt the competitive playing field, of federal bureaucrats to expand their regulatory mandates, and of Progressive reform interests to ensure that consumers were not deceived about the quality of food and drugs they purchased. Even so, while several pure food and drugs bills were considered during the 1890s and early 1900s, none were passed. Conflict among these competing interests made

\footnotetext{
${ }^{2}$ Until the late 1920s, the organization that we know today as the FDA was the Bureau of Chemistry, an agency within the federal Department of Agriculture. In 1927 the regulatory portion of this agency was re-named the Food, Drug and Insecticide Administration. In 1930 its name was shortened to the Food and Drug Administration.
} 
it impossible to form an enacting political coalition. In 1905-06, however, with the publication of Upton Sinclair's The Jungle along with sensational muckraking articles in leading magazines and newspapers, popular opinion in favor of food and drug regulation was electrified, and this in turn facilitated the formation of an effective coalition in favor of final passage of the law.

We also find that because the interests behind the legislation were unable to entirely shape the enforcing agency or the legal environment in which enforcement took place, these groups did not ultimately benefit from regulation as initially anticipated. Accordingly, while a combination of the three views of regulation furnishes an explanation for why regulation arose at the time that it did, it does not provide a complete account of the ultimate effect of policy. A more eclectic approach that takes into account the abilities of interest groups to influence the institutional environment is needed to fully understand the causes and consequences of Progressive Era regulation.

\section{Market Changes and a Conceptual Framework for Analysis of Reform}

Three important developments characterized the market for food and drugs in the late nineteenth and early twentieth centuries. The first was the introduction of new and cheaper food and drug products that threatened to erode the dominant position enjoyed by older products. These competitive changes gave rise to trade wars among rival firms. The second was scientific advance that increased the complexity of many products. This situation created opportunities for cost-saving deception by some firms through alteration or adulteration of their products in ways that consumers could not easily perceive. Uncertainty about product quality, in turn, placed consumers at risk of being cheated 
about quality or, more ominously, of being poisoned. The third was the creation of national markets that affected consumers, producers, and government agencies. Increasingly, consumers purchased food and drugs that were made in other states, often outside the jurisdiction of local or state courts and regulatory bodies. In disputes over product quality, individual state regulations and tort actions were ineffective as remedies. Additionally, firms producing for the national market were faced with different and often conflicting regulatory environments that made compliance and product standardization difficult. Growing interstate trade and general concerns about product safety therefore created new opportunities for federal regulators to extend their mandates. In contrast, state regulatory officials were often jealous of their prerogatives and suspicious of any expansion of federal authority. All in all, these developments in the market for food and drugs meant that the demand for federal regulation during the Progressive Era could come from three different sources:

\section{A. Regulation as a Solution to Market Failure}

Asymmetric information about product ingredients and product quality created concerns that there was a "lemons" problem in the market for many food and drug items (Akerlof 1970). Because consumers could not detect many forms of food and drug adulteration, markets could not always guarantee the delivery of quality food and drug products (Darby and Karni 1973; McCluskey 2000). Hence, there was a productive role for product quality regulation by scientific experts, who had a comparative advantage in judging the quality of food and drug items. Since national markets were involved, federal politicians could improve consumer welfare and also garner votes by adopting federal regulatory legislation. Under this view there was a market failure to be corrected and the 
Pure Food and Drugs Act and its administering agency were a means of solving the problem; regulation was consumer driven and aimed at solving real economic problems.

\section{B. Rent-seeking Through Regulatory Capture}

An alternative view based on the work of Kolko (1963), Stigler (1971), and Peltzman (1976) highlights the role of regulation in advancing specific producer interests rather than the efficiency gains from regulation. Firms captured the regulatory process in order to raise the costs of their rivals through constraints on entry or other production restrictions (Wood 1986). This action benefited firms that sought to mitigate any advantages their rivals gained from the adoption of new production technologies. Politicians responded because these groups could offer votes and campaign contributions in exchange. At the state level, some laws were designed to strategically advantage local and regional producers who faced new interstate competitive pressures. More national producers and interest groups, in contrast, sought federal legislation to create uniform regulatory standards, thwart more aggressive state regulation, and to disadvantage other producers. If the regulations were effective, successful producer groups could secure monopoly rents through higher prices and reduced output. Hence, under this view, the principal advocates of the legislation were industry groups seeking pecuniary advantages relative to their rivals. The Pure Food and Drugs Act was an example of the capture of government by business interests, and the Bureau of Chemistry and FDA were agents of that capture. The distributional gains secured by business offered no consumer benefits. Indeed, by restricting entry consumers may have been harmed by enactment of the law.

\section{Rent-seeking by Enterprising Federal Bureaucrats and the Press}


A final possibility emphasizes the roles played by entrepreneurial federal bureaucrats seeking to expand their jurisdictions and agency budgets (Niskanen 1971) and by muckraking journalists seeking to sell newspapers, magazines, and books. These two parties formed a natural alliance in favor of regulation because the press could publicize the self-serving "scientific" concerns of federal regulators about food and drugs safety. Muckraking publications could galvanize public support for regulation through grisly tales about consumers being defrauded and even poisoned. Additionally, sensational muckraking disclosures attracted readers. These claims were credible because new production technologies and products were not well understood by consumers and their quality and health effects could not be easily assessed. If regulation were adopted by taking advantage of limited consumer and voter information, it too would provide little or no welfare gains for consumers. Accordingly, under this view, consumers were manipulated by an aggressive press and federal bureaucracy seeking to exploit their ignorance of the content of new products and processes. Enactment of the Pure Food and Drugs Act was less a response to real economic problems than to rising consumer concerns fueled by a newly effective, sensational media. The major proponents of the law then were consumer groups, the muckraking press, and federal bureaucrats.

To see how each of these views performs in explaining the adoption of federal regulation we turn to an examination of the market for food and drugs in the late $1800 \mathrm{~s}$ and the legislative history of federal food and drugs regulation.

\section{Market Changes and the Legislative History of Federal Regulation}


Regulation may have had multiple advocates with different objectives. The key constituencies potentially involved in food and drugs regulation include ideologicallymotivated Progressive reformers, state regulators, federal regulators, incumbent firms producing "old" goods and entrant firms producing "new" goods, the muckraking press, and consumers. These parties had conflicting incentives for federal regulation of product quality. These differences shaped political constituencies as well as the nature of the conflict surrounding proposed pure food and drugs bills.

\section{A. The Changing Market and Producers' Incentives to Lobby for Regulation}

Expanding markets combined with advances in food processing gave rise to new products that better met the needs of certain market segments and were cheaper than those produced by older firms. These older firms thus had an incentive to organize to obtain government support in blocking or limiting the spread of these new products.

Consider the following products and their impacts on the market. Oleomargarine, the first viable butter substitute, was introduced to the American market in the early 1870s. Invented in 1869 by the French chemist, Mège-Mouries, oleomargarine (margarine) quickly became popular among working-class households because it was considerably cheaper than butter (Dupré 1999). Similarly, declining transportation costs and the development of the refrigerated rail car made it possible for large meat packinghouses located in Chicago, St. Louis and other mid-western cities to slaughter cattle centrally and ship prepared beef carcasses (known as "dressed beef") to eastern markets. By the 1880s, sales of "dressed beef" rivaled sales of locally slaughtered meat in New York, Boston, and other cities on the east coast (Yeager 1981; Libecap 1992). Advances in chemistry gave rise to a new form of baking powder-alum based baking 
powder - that was cheaper than traditional cream of tartar baking powders. Additionally, other improvements in canning and preserving technology made it possible to expand both the geographical and temporal distances between the production and consumption of fruits, vegetables, meats, and seafood.

As a consequence of these developments, conflicts among competing factions of the food trade became common. Dairy producers, threatened by the growing popularity of oleomargarine, slandered oleomargarine as "the greasy counterfeit" and, importantly, sought regulations at the state and federal level to stem the growth of the oleomargarine trade. Local butchers, in concert with disgruntled cattlemen, charged that dressed beef was unsafe, and lobbied for meat inspection and antitrust to disadvantage the large Chicago packinghouses. A long and protracted battle emerged between the cream of tartar baking powder interests and the alum-based baking powder interests, each of whom charged that the other product was dangerous to health and attempted to obtain regulation that disadvantaged the other product. Similar conflicts also arose between "straight" and "blended" whiskey producers, each claiming that the other product was impure and unsafe for consumers. The arrival of newer, cheaper substitute products clearly stimulated a demand for regulation on the part of certain producer groups who desired regulation as a way of shifting demand away from competing products (Wood 1986, 152-80).

Indeed, some of the laws regulating the food industry were closely tied to the efforts of industry groups to weaken their rivals. For instance, regulations enacted by state governments that required oleomargarine to be colored differently than butter, that prohibited the use of oleomargarine in boarding houses, prisons, or in restaurants, or that tightly regulated or even prohibited its sale were enacted primarily to benefit dairy 
farmers. Further, the 1886 Oleomargarine Tax enacted by Congress required oleomargarine producers to mark and stamp their product in various ways, imposed an internal revenue tax of $\$ 0.02$ per pound on oleomargarine, and levied a fee of $\$ 600$ per year on oleomargarine producers, $\$ 480$ per year on oleomargarine wholesalers, and $\$ 48$ per year on oleomargarine retailers (US Senate 1900-01; Lee 1973; Dupré 1999).

Correspondingly, the 1891 Meat Inspection Act was enacted in part to satisfy a coalition of cattlemen and local butchers in eastern markets, who wanted regulation that would stem the growth of the "dressed" meat trade and disadvantage the large Chicago packers. The large packers, however, also supported the law because it helped to create foreign markets for their meats by requiring inspection of cattle and hogs destined for interstate and foreign commerce (Libecap 1992).

\section{B. The Changing Market and Consumers' Incentives to Secure Regulation}

Consumers also had reasons to be worried about changes in the market for food and drugs. As food production moved out of households and into impersonal markets, and as foods became more sophisticated as a result of advances in manufacturing and processing, it became increasingly difficult for ordinary consumers to discern product quality and composition. Fears about the quality of food products—-specifically about the ingredients contained in foods, as well as in the nutritional value of foods containing chemicals, preservatives, and other manufactured components—-began to be expressed by chemists, home economists, public health officials, and other reform-minded individuals. These parties expressed their concern for consumer welfare by highlighting the potential problems and by calling for a more active role for government. 
For instance, there was a burgeoning literature on how food was "adulterated" (i.e. cheapened through the addition of impurities) by manufacturers and distributors in an effort to obtain dear prices for cheap items, and on the consequences of food adulteration for health and longevity. "We buy everything, and have no idea of the processes by which articles are produced, and have no means of knowing beforehand what the quality may be," wrote Ellen Richards, one of the leaders of the home economics movement, in her 1885 book entitled Food Materials and Their Adulteration. "Relatively we are in a state of barbarous innocence, as compared to our grandmothers, about the common articles of daily use" (quoted in Strasser 1989, p. 255). Asymmetric information about food ingredients thus gave rise to the perception that there was a "lemons" problem in the markets for many food and drug items.

State and federal agencies were attracted to the issue, and studies conducted by analytical chemists employed in state and federal public health and agricultural departments revealed extensive food adulteration. According to a 1902 Senate Report that surveyed the findings of several adulteration studies conducted during the prior two decades, food adulteration was reasonably common (U.S. Senate 1902). Numerous independent studies found that milk was watered down or skimmed without warning. Others found butter to be cheapened by the addition of oleomargarine. Cotton-seed oil was often added to lard that was marketed as "pure leaf lard." Glucose and chemical preservatives were frequently added to canned and prepared goods without indication on product labels. Many of these actions were documented in 1887 in Food Adulteration and Its Detection by J.P. Battershall, a chemist employed by the U.S. Public Health Department. 
Claims were also made by advocates of regulation that adulterated food posed health risks, but the available evidence was more mixed, perhaps because understanding about the basics of human nutrition was very primitive at the time, even among leading physicians and public health officials. In testimony to Congressional hearings on food adulteration in the late 1890s and early 1900s, physicians and scientists disagreed about the nutritional value of preservatives like borax and salicylic acid, about the effects on human digestion of alum based as opposed to cream of tartar based baking powders, and about the health risks associated with the consumption of artificial sweeteners like glucose (U.S. Senate 1899-1900; Young 1989, 140-45).

Charges that particular food products were poisonous and could lead to death were largely unsupported, since there was little evidence of widespread poisonings resulting from the consumption of dressed beef, canned fruits, vegetables and meats, or other manufactured and processed food items. ${ }^{3}$ Much of the scientific debate involved government officials, and it centered on the more subtle consequences of food consumption on digestion and nutrition.

Reputation mechanisms may have been a market solution for reducing consumer uncertainty about food quality. Product branding proliferated as producers of canned and processed foods like Swift, the National Biscuit Company, and H.J. Heinz worked to establish reputations for providing high quality products (Strasser 1989). Retail grocery chains like A \& P and Krogers also emerged in the late 1800s, partly in response to the need to assure consumers of the quality of foodstuffs (Kim 2001).

\footnotetext{
${ }^{3}$ Olmstead and Rhode (2004) report a more direct growing human health threat through bovine tuberculosis. Federal regulatory responses began in 1913.
} 
In general, however, it was not possible for consumers to know if the foods they ate were harmful or healthful, or if chemical preservatives or low quality ingredients had been added to their food. Hence, market-based solutions to the asymmetric information problem, which relied on ex post verifiability of product quality, likely were insufficient to guarantee the delivery of those dimensions of quality that had "credence" characteristics (Darby and Karni 1973; McCluskey 2000). This sentiment was expressed by a member of the Forty-Ninth Congress (1885), who made the following argument in a speech to the House on the need for pure food regulation:

In ordinary cases the consumer may be left to his own intelligence to protect himself against impositions. By the exercise of a reasonable degree of caution, he can protect himself from frauds in under-weight and in under-measure. If he can not detect a paper-soled shoe on inspection, he detects it in the wearing of it, and in one way or another he can impose a penalty upon the fraudulent vendor. As a general rule the doctrine of laissez faire can be applied. Not so with many of the adulterations of food. Scientific inspection is needed to detect the fraud, and scientific inspection is beyond the reach of the ordinary consumer. In such cases the Government should intervene (Congressional Record 1885, 5040-41).

Concerns about food quality generated demand for food regulation among advocates for consumers. Progressive reform groups—most notably women's groups like the General Federation of Women's Clubs (GFWC), the Women's Christian Temperance Union (WCTU), as well as leaders of the home economics movement and public health officials—-lobbied for regulations that banned the sale of adulterated and misbranded food products.

Accordingly, some of the food regulations enacted during the Progressive Era appear to have had clear public interest motivations. In particular, the general pure food and dairy laws enacted by state governments during the last two decades of the nineteenth century were aimed at improving the accuracy of product labels. While the content and 
form of these laws varied somewhat from state to state, in general the goal of these regulations was to ensure that mixtures and impurities that were added to products be indicated clearly on product labels. In so doing, these state pure food laws helped solve a lemons problem in the market for many food products. This action benefited certain consumers, who desired better information about product quality, as well as higher quality producers, who felt that regulation would help them segment the market for their wares (Law 2003).

\section{Market Changes and Government Officials' Incentives to Secure Regulation}

Efforts to expand regulation provided opportunities for state and federal bureaucracies to increase their budgets, staffing and authority. Regulation by "experts" made sense to advocates because chemists and other scientists employed in government agencies had a definite comparative advantage over consumers in detecting food adulteration. Indeed, during the 1880s and 1890s, most state governments enacted "pure food" and "pure dairy" laws that outlawed the sale of adulterated foods, and that gave officials employed in state pure food agencies the authority to seize adulterated and misbranded products and prosecute manufacturers and dealers who violated these regulations (U.S. Senate 1900-01).

By the 1890s, however, it became clear that state governments were not optimally positioned to systematically regulate the content of food labels. This was for three reasons. First, the expansion of interstate trade in food products made it increasingly difficult for state governments to regulate goods produced out-of-state or even enforce their own pure food laws. Although state governments had the authority to regulate goods 
produced and sold within their borders, they had no authority over the production of goods in other states and could not control the sale of out-of-state goods sold within their boundaries. By shipping goods in an "original and unbroken package," out-of-state manufacturers and distributors could circumvent a state's pure food regulations (U.S. Senate 1899-1900, p. 529-530).

Second, the pure food laws enacted in many states were often not enforced. Although nearly every state enacted a pure food law between 1880 and 1900, only half of these state laws entrusted enforcement to a particular state agency (Law 2003). The pure food laws enacted by the remaining states were essentially window-dressing laws that had little bite. Narrative evidence presented by Goodwin $(1999,68-70)$ suggests that enforcement was limited or even non-existent in those states that did not have an enforcement agency. While there is some evidence that lax enforcement in some states may have been in response to pressure from particular food manufacturers (Okun 1986), a close examination of Congressional testimony on proposed food and drug bills and other contemporary sources does not suggest that "corruption" of state regulators by industry interests played a systematic role in undermining state efforts. Regulation was lax in many states not because manufacturers deliberately made it so, but rather because government in general was small and budgets were limited. As a result, pure food regulations in many states did little to solve the asymmetric information problem regarding product ingredients.

Finally, in testimony to Congress, manufacturers and distributors engaged in interstate trade in foodstuffs also complained that compliance with several different state regulations was costly. These manufacturers and distributors desired a uniform federal 
pure food law because they felt that it would reduce compliance costs and because a national law might preempt more onerous state regulation. For instance, according to the director of a large Chicago wholesaler:

The various states throughout this country... have passed pure-food laws, and in the distribution of merchandise - some kinds of merchandise - I find that at times errors are very likely to crop up in the shipping of goods in these states on account of the lack of uniformity, as the law of one State differs from the law of another, so that for the last ten years the merchants and manufacturers of Chicago have been clamoring for a national pure-food law, in the same manner that we clamored for a national bankruptcy act. It requires a lawyer for each State to know what the requirements are in each state in order to know the rules that prevail in them (U.S. Senate 1899-1900, 73).

As the push for federal regulation intensified, however, conflict arose among bureaucrats at the federal and state level regarding who should enforce a federal pure food law, and who should have authority to set food standards. Beginning in 1887, the Bureau of Chemistry, an agency within the Department of Agriculture, began to publish several high profile studies documenting the nature and extent of food adulteration in the United States. Under the leadership of Dr. Harvey Wiley, the Bureau of Chemistry began to develop a reputation for its analysis of food adulteration in America. By the mid-1890s it became clear that the Bureau of Chemistry would become the agency responsible for enforcing a federal pure food and drugs law.

Federal officials within the Bureau of Chemistry faced a strong incentive to lobby for federal pure food regulation since they would capture the benefits of regulation through an expansion of their regulatory mandate. Regulators from some states opposed federal regulation, partly because it had the potential to make them redundant, but also because they were suspicious that federal regulators (specifically, Harvey Wiley) would not be independent of certain manufacturing interests with whom Wiley had ties. On the 
other hand, the Association of Official Agricultural Chemists (AOAC) as well as regulators from other states were solidly behind Harvey Wiley and the Bureau of Chemistry. Jockeying among bureaucratic interest groups thus also contributed to political stalemate over regulatory reform (Coppin and High 1999).

\section{Political Stalemate and the Muckraking Press in the Timing of Regulation.}

The conflicting objectives of business, consumer, and state and federal government interests created a political stalemate and blocked action at the federal level for food and drugs regulation. Consider for example, the Paddock Bill, introduced in 1890 by Senator Paddock of Nebraska to protect producers and consumers against commercial fraud in food products (adulteration) and to improve the reputation of American food products abroad and thereby promote exports. Despite claims of widespread support for the bill from citizens, state legislatures, wholesale grocery and drug associations, boards of trade, and farm organizations, no action was taken in 1890 or 1891. Corn and hog producers, who were waging a trade war against "adulterated" lard that had cottonseed oil added to it were strong advocates, and in 1892 the bill was reintroduced to the Senate in a weakened form. It passed the Senate, but in the House cottonseed oil producers, through their Congressional representatives, were able to prevent it from becoming law (Anderson 1958, 78-80; Young 1989, 97-99).

Similarly, competing baking powder interests stalled other federal pure food bills. In these cases, producers of cream of tartar baking powders wanted the regulations to be written in a way that put alum-based baking powders at a competitive disadvantage. Naturally, producers of alum based baking powders wanted assurances that the regulations would not be enforced in a way that discriminated against their product. 
Hence, according to Anderson (1958, p. 135), by 1900 "[t]he situation had reached a point where, no matter how the bill was phrased, it would encounter opposition from either of the two great camps of baking powder producers."

Additionally, conflict among straight and blended whiskey producers contributed to political gridlock over efforts to secure a pure food law in the early 1900s. Straight (distilled) whiskeys, produced in Kentucky, Maryland, Virginia and Pennsylvania, competed with cheaper "blended" (rectified) whiskeys, produced in Illinois, Indiana, and Ohio. Straight whiskey interests, who were the incumbent producers, viewed blended whiskeys as "impure" products and sought regulation that would disadvantage blended whiskies, which were rapidly gaining market share. Pure food bills were drafted to require that "mixtures, compounds, combinations, imitations or blends" (blended whiskey) be "labeled, branded, or tagged, so as to show the character and constituents thereof."4 Concerned that this clause would force blended whiskey manufacturers to disclose valuable trade secrets, the National Wholesale Liquor Dealers' Association, the trade organization of blended whiskey producers, organized successfully to fight these bills (Young 1989, 165-68).

Finally, disagreement over whether pure food regulation should include medicines, in particular, drugs that were not listed in the United States Pharmacopoeia $(U S P)$ or the National Formulary (NF), also generated political opposition to federal regulation. Selected Progressive reform groups, in particular women from the WCTU, wanted patent medicines and proprietary nostrums to be regulated because of their

\footnotetext{
${ }^{4}$ According to Young $(1989,167)$, Wiley "abominated" blended whiskey and "leagued with the distillers to plot ways of checkmating the blenders' stratagems."
} 
alcohol content. Organized medicine, represented by the American Medical Association (AMA), also desired regulations that limited the availability of "quack" drugs (Anderson 1958, 169-71). The AMA was motivated in part because of the health risks posed by patent medicines, but also because, by functioning as a substitute for physicians' services, patent medicines were a competitive threat to physicians.

The trade organizations for patent medicines, the Proprietary Association, other drug producers, as well as newspapers that were dependent on patent medicine advertising as a source of revenues, lobbied against proposed pure food and drug regulations that would include drugs not listed in either the USP or $N F{ }^{5}$ They feared that the federal government would begin to regulate the therapeutic claims made about their products. According to the Proprietary Association's Committee on Legislation, regulation that defined drugs more broadly "would practically destroy the sale of proprietary remedies in the United States" (quoted in Young 1989, 169).

These legislative conflicts may have effectively prevented adoption of any federal law had it not been for the rise of muckraking journalism and its sensational claims that raised the political costs of opposing regulation. Indeed, muckraking journalism, by making the issue of food and drug adulteration emotionally salient, served as a coordinating device through which diffuse consumer interests were harnessed.

Several factors contributed to the appearance of muckraking journalism in the late 1800s, and these factors were closely tied to the undercurrents of Progressive reform more broadly and to food and drugs regulation more specifically. Many Progressive

\footnotetext{
${ }^{5}$ Patent medicines were in fact among the most important sources of newspaper and magazine advertising revenues during this period. See Young (1967).
} 
reformers were writers and journalists, who believed in the "power of the pen" to inform readers of social and economic problems and to persuade ordinary citizens of the need for reform (Hays 1957). Further, technological and organizational developments made it possible for these writers and journalists to reach a larger audience than ever before. The adoption of high-speed presses and the perfection of halftone photoengraving reduced production costs and improved the quality of illustrations. Declining postal rates during the 1880s and 1890s lowered the cost of distributing periodicals throughout the nation. The growth of a national market for consumer products and the sale of magazine and periodical space to national advertising companies made it possible for periodicals to be sold to consumers at extremely low prices (often less than 10 cents per copy). Owners of periodicals like McClure's, Cosmopolitan, Colliers Weekly, Everybody's, and Munsey's soon discovered a profitable combination in the marriage of low cost, high distribution, advertising-intensive magazines with sensational journalism that exposed readers to important social and economic problems (Chalmers 1974; Filler 1976). Hence, muckraking journalists like Samuel Hopkins Adams, Ray Stannard Baker, Henry Demarest Lloyd, Upton Sinclair, Lincoln Steffens, Charles Edward Russell, and Ida Tarbell were hired by these periodicals to write articles exposing unscrupulous business practices, slum urban conditions, and political corruption.

Two major muckraking episodes appear to have especially critical in enactment of the Pure Food and Drugs Act (Anderson 1958; Young 1989; Carpenter 2001). One was the publication in 1906 of Upton Sinclair's The Jungle, which exposed unsanitary conditions in Chicago meat packing plants and generated public outrage over the quality 
of meat. ${ }^{6}$ First published as a serial in the muckraking journal Appeal to Reason, Sinclair's novel revealed how the large meat packers deceived consumers about the quality of their products. Sinclair described how "potted chicken" contained no chicken at all; how meat that had turned sour was rubbed with soda to remove the smell; how moldy sausage rejected from Europe found its way back into the American market; and how meat was contaminated on the slaughterhouse floor. The direct result of Upton Sinclair's muckraking was the 1906 Meat Inspection Act, which significantly expanded USDA's inspection of the slaughtering, packing, and canning of meats (Young 1989, 221-50).

The second muckraking episode was a set of articles published in Colliers that revealed the how patent medicine manufacturers were using their power over the press to defeat state regulation, but more importantly, alerted the public to the dangers associated with the use of patent medicines. In a November 4, 1905 article, "The Patent Medicine Conspiracy against the Freedom of the Press," Mark Sullivan exposed the influence of the patent medicine industry over the press and state efforts to regulate proprietary remedies. This attack on the nostrum industry was accompanied by a series of articles by Samuel Hopkins Adams, also published in the autumn of 1905, which pointed to the dangers associated with the indiscriminate use of patent medicines and the widespread presence of alcohol and opiates in these drugs. "Gullible America," wrote Adams, "will spend this year some seventy-five million dollars in the purchase of patent medicines. In consideration of this sum it will swallow huge quantities of alcohol, an appalling amount

\footnotetext{
${ }^{6}$ Sinclair's main objective in writing The Jungle was to provoke outrage over industrial working conditions of immigrants, rather than to reveal deception on the part of the meat packers. regarding product quality. See Young $(1989,252)$.
} 
of opiates and narcotics, a wide assortment of varied drugs ranging from powerful and dangerous heart depressants to insidious liver stimulants; and, far in excess of all other ingredients, undiluted fraud" (quoted in Carpenter 2001, 269).

The effect of Adams's muckraking about patent medicines on the progress of regulatory reform was dramatic. By making the public aware of the dangers of patent medicines, Adams informed citizens of the possible public benefits of regulation and therefore provided consumers with a stronger incentive to lobby actively for food and drugs regulation. Congress was thus inundated with petitions from women's groups and other consumers throughout the country who demanded regulation of patent medicines. Harvey Wiley and the Bureau of Chemistry supplied chemical analyses of patent medicines to advocate groups who desired more evidence of their dangers. Adams's articles were reprinted in the Journal of the American Medical Association and distributed to physicians throughout the country, who in turn lobbied Congress for regulation (Anderson 1958, 172-80; Carpenter 2001, 269-70).

Muckraking journalists clearly benefited from the increased sales and prestige generated by their revelations. However, since the Bureau of Chemistry was the organization that would be empowered to enforce a federal food and drug law, it is not surprising that Wiley, more than any other individual in the federal bureaucracy, tirelessly strove to drum up political support for a federal food and drugs law. For instance, during the early 1900s, Wiley conducted a series of high profile experiments on USDA employees (who became popularly known as the "poison-squad") on the effects of preservatives on human digestion. Wiley also spoke regularly at women's club events about the extent of food and drug adulteration and its consequences for human health 
(Carpenter 2001, 263-66). Additionally, a close relationship between Adams and Wiley was forged as the former gathered materials for his Colliers articles (Young 1989, 203). The alliance between the Bureau of Chemistry and a muckraking press was vital in forging an enabling political coalition to enact a federal food and drug law.

\section{Econometric Analysis of the Theories of Progressive Era Reform}

The legislative history of the Pure Food and Drugs Act suggests that each of the three views of Progressive Era reform contributed to the adoption of federal food and drugs regulation. We now turn to an econometric analysis of congressional voting on two key food and drug bills to provide an additional empirical test of these three hypotheses. By correlating congressional voting on proposed pure food bills with variables that capture the influence of different groups, we can illustrate how competing interests aligned themselves over regulation. Evidence that proxies for key producer and consumer interests influenced congressional voting provides support for the regulatory capture and public interest views of regulation. Additionally, by comparing votes on food and drug legislation before and after the muckraking episodes of 1905, we can determine the effect that the muckraking press and its bureaucratic allies had on the enactment of legislation, which provides a partial test of the third hypothesis for regulation.

Unfortunately, roll call data on congressional votes on the various pure food and drug bills introduced prior to 1905 is scarce. Bills never reached a vote or if they did, no roll call was tabulated. Prior to the February $21^{\text {st }}, 1906$ Senate vote on the bill that became the Pure Food and Drugs Act, we were only able to find one recorded roll call vote of interest to us: the March $3^{\text {rd }}, 1903$ Senate vote on whether or not to consider the 
Hepburn/Hansborough bill. This bill was very similar to the 1906 law. It called for federal regulation of patent drugs not listed in the $U S P$ or the $N F$ and it required disclosure of ingredients aimed particularly at blended whiskeys and food manufacturers who used preservatives in their products.

Hence, for our empirical analysis, we examine how different interest groups with a stake in the legislation shaped Senate voting on March $3^{\text {rd }}, 1903$ and February $21^{\text {st }}$, 1906.

\section{A. Econometric Analysis of Senate Voting in 1903}

By 1903 the main interests that were engaged in the debate over pure food and drug regulation were: (i) patent medicine manufacturers and organized medicine, who opposed or supported the Hepburn/Hansborough bill because of its patent drugs regulation; (ii) food manufacturers who used preservatives and glucose, who feared that regulators would target their items unfairly; (iii) straight and blended whiskey manufacturers, who took opposing sides on the pure food issue; (iv) large food manufacturing firms engaged in interstate trade, who desired federal regulation in order to reduce regulatory compliance costs; and (v) consumer-oriented Progressive reform groups who desired regulation in order to improve the informational accuracy of product labels. In our regression framework, we include variables that capture the influence of these interest groups in each state. We also control for party membership and include first dimension D-Nominate scores to hold constant a Senator's ideology. Descriptive statistics for the regression variables are shown in Table 1.

Column 1 of Table 2 displays probit regression estimates of the factors shaping Senate voting on whether or not to consider the 1903 Hepburn/Hansborough Bill. The 
marginal effects of each of the explanatory variables (evaluated at their means) on Senate voting are shown in the first column of Table 3. Overall, the regression results are consistent with the qualitative evidence on the configuration of producer and consumer interest over food and drugs regulation. The results also are supportive of the capture view of regulation, but provide more limited support for the public interest view. Other things equal, an increase in the size of the patent medicine industry in a state had a negative and statistically significant effect on the probability that a Senator from that state would vote in favor of the bill. Additionally, an increase in the number of physicians per capita in a state, a measure of the established medical industry, had a positive, but not significant effect on the likelihood a state's Senator would vote in favor of the bill. In states where blended whiskeys were produced, Senators were less likely to vote for regulation whereas in states where straight whiskeys were manufactured Senators were more likely to vote for regulation. An increase in the number of food manufacturers in a state who used preservatives (proxied by membership in the National Food Manufacturers Association or NFMA) had a negative but statistically not significant influence over the likelihood that a state's Senator would vote in favor of pure food regulation. Reform interests (proxied by WCTU dues per capita and the Protestant Index) had a positive, but statistically insignificant impact on the probability that a Senator would vote in favor of regulation. $^{7}$

\footnotetext{
${ }^{7}$ Qualitatively similar results were obtained when we used WCTU membership per capita (instead of WCTU dues per capita) to proxy for reform interests. Additionally, the inclusion of income per capita does not materially affect the results. The Protestant Index measures the presence of evangelical, Protestant groups in each state. This is a reasonable proxy for Progressive reform interests, since membership in Progressive reform groups was heavily dominated by evangelical Protestants.
} 
The coefficient estimates suggest that those producer interests who perceived that regulation would disadvantage their products (patent medicine makers, blended whiskey producers, and firms who used preservatives) opposed regulation, whereas those who felt that regulation would place them at a competitive advantage and who played a role in shaping the features of the proposed food and drug bill (organized medicine, straight whiskey makers) supported it. The fact that Senators representing organized medicine and straight whiskey interests were more likely to vote for regulation is consistent with the regulatory capture argument since both of these groups sought regulation to disadvantage their lower-cost rivals. While the coefficients on the reform interest variables are both positive, they are not significant, which furnishes weak evidence consistent with the public interest hypothesis. That these reform interest variables are not significant is perhaps unsurprising, since consumers, being a large and heterogeneous group, faced high collective action costs (Olson 1965).

Among the political control variables, Republican Party membership does not play a significant role in voting in 1903, but the D-Nominate score has a significant and negative coefficient. More positive D-Nominate scores indicate a more conservative ideology, and such ideologically motivated Senators were more likely to vote against an extension of federal regulation.

\section{B. Econometric Analysis of Senate Voting in 1906}

We can empirically evaluate the role that muckraking journalism played in breaking the political deadlock over pure food and drug regulation by examining the factors that shaped Senate voting in 1906 on the bill that became the Pure Food and Drugs Act. In our analysis of Senate voting in 1903 (the pre-muckraking period) we 
found that patent medicine and blended whiskey interests had a negative and statistically significant influence on the probability that Senators would vote in favor of considering the Hepburn/Hansborough bill, while reform interests had a positive but statistically insignificant influence on Senate voting. If muckraking journalism about patent medicines (which began around October 1905 with the publication of Samuel Hopkins Adams's articles in Colliers) provoked widespread consumer interest in favor of regulation, it would have helped to break the political deadlock over food and drug regulation. Accordingly, in an examination of Senate voting in the post-muckraking period (after October 1905), anti-regulation producer interests should be less likely to have a negative and significant influence over Senate voting, and Progressive reform interests should have a positive and significant influence over Senate voting. Antiregulation producer interests should be less significant because muckraking should have made it more costly for politicians representing these groups to continue to oppose regulation. Reform interests should become significant factors influencing Senate voting if muckraking, by increasing the perceived benefits of food and drugs regulation, galvanized consumer-oriented groups to actively pressure politicians to back reform.

Column 2 of Table 2 presents probit regression estimates of the factors shaping Senate voting on February $21^{\text {st }}$, 1906; the corresponding marginal effects are shown in the second column of Table 3 . The coefficients representing blended whiskey and patent medicine interests are no longer statistically significant, whereas one of the coefficients representing reform interests (WCTU dues per capita) is positive and significant. These post-muckraking regression results conform to our predictions regarding the role that muckraking journalism played in breaking the political deadlock over regulatory reform. 
By making the issue of food and drug quality emotionally salient, muckraking provoked pro-consumer interests to lobby for regulation, and made it more costly for politicians representing anti-regulation business groups to continue to block regulation. In our regression framework, this is suggested by the fact that one of our proxies for reform interests is now positive and significant, while our proxies for patent medicine interests and blended whiskey interests are no longer significant. ${ }^{8}$

The Republican Party variable becomes positive and significant in 1906, reflecting President Theodore Roosevelt's efforts to push his party in Congress to support food and drug regulation in the wake of the publication of Upton Sinclair's The Jungle (Anderson 1958, 181; Young 1989, 254). Prior to 1905-06, food and drug regulation was not a particularly partisan issue. The D-Nominate variable no longer has a significant effect on Senate voting. With consumer/voter reaction to muckraking revelations, it became more costly for conservative Senators to continue to oppose regulation, making ideology less important.

Overall, these regression results provide evidence supporting each of the three views of regulation. The straight whiskey variable and the number of physicians per capita are positive and significant, which supports the regulatory capture hypothesis for regulation. WCTU dues per capita also have a positive and significant effect on the probability that a Senator voted for regulation. This suggests the importance of organized consumers as a pro-regulation constituency, which is consistent with the public interest view. However, the fact that this variable is positive and significant in 1906 (post-

\footnotetext{
${ }^{8}$ As before, we find that using WCTU membership per capita yields qualitatively similar results. Additionally, the coefficient estimates are robust to the inclusion of other
} 
muckraking) but not in 1903 (pre-muckraking) suggests that the muckraking press and its bureaucratic supporters also played an important role in generating broad consumer interest in regulation. Hence, taken together, the evidence is also consistent with the possibility that consumers were manipulated by a muckraking press.

\section{Enforcement of the Pure Food and Drugs Act and the Long-Term Benefits of Regulation}

Given that a mixture of consumer, industry, and bureaucratic interests were involved in the struggle for federal food and drugs regulation, it is worth asking about the welfare implications of this law. Was federal regulation, once enacted, enforced in a way that benefited specific industry groups at the expense of competitors and overall economic efficiency? Or did enforcement of the Pure Food and Drugs Act ultimately produce benefits for consumers and improve the efficiency of food and drugs markets?

It is difficult to address these issues because few scholars have systematically analyzed the impact of the Pure Food and Drugs Act on the markets for food and drugs. Nevertheless, what we know about enforcement of the law suggests that no view on its own is satisfactory. The evidence on early enforcement of the act (under the stewardship of Dr. Wiley) suggests that certain industry groups were favored, which would be consistent with the regulatory capture view. According to Coppin and High (1999), Wiley attempted to enforce the law in ways that favored straight whiskey makers and that advantaged manufacturers that did not use preservatives in their foods. Controversy surrounding Wiley's enforcement efforts and Wiley's resignation from the Bureau of

variables like income per capita. 
Chemistry in 1911, however, prevented these groups from obtaining longer-run benefits. While certain industry interests may have "captured" Wiley, their influence did not extend to his successors or to the Bureau more generally. Indeed, the personnel of the Bureau and its leadership in the post-Wiley period consisted primarily of professional bureaucrats, whose interests were not closely aligned with industry. Hence, because those pro-regulation industry groups who stood to gain most from regulation did not ultimately control the administering agency, they did not realize the expected long-term benefits from reduced competition from substitute products. This outcome weakens the argument in favor of a regulatory capture view of regulation.

Did consumers then capture the benefits of regulation? The evidence from the post-Wiley period suggests that although the Bureau of Chemistry attempted to enforce the Pure Food and Drugs Act in ways that improved the quality of food and drugs and that reduced asymmetric information about food and drugs quality, the Bureau was not always successful in achieving these objectives. Because the Bureau was small with limited resources, and because the Pure Food and Drugs Act was difficult to enforce in the courts, the agency relied upon rewards to firms that complied with the law. For instance, as one way to promote compliance with the law, it provided quality certification and direct technical advice on how to improve product quality (Law 2004). Effective enforcement, when it happened, generally yielded socially beneficial outcomes; the Bureau's product certification efforts reduced asymmetric information about the quality of foodstuffs, and as a consequence of offering technical assistance to firms, the quality of many foods improved (Robinson 1990; Young 1992). 
These efficiency-enhancing outcomes are more consistent with the public interest view than the regulatory capture view. Certain producers benefited from these enforcement efforts because they were assisted by the Bureau's expertise, but there were few restrictions on entry, the classic capture objective. Nevertheless, it is notable that enforcement successes could only be achieved when industry also stood to gain from the Bureau's expertise. ${ }^{9}$ When industry could not benefit from the Bureau's actions, effective enforcement was unlikely since it was difficult for the agency to prosecute manufacturers in court. For instance, the 1912 Sherley Amendment to the law required the agency to prove fraud in order to obtain a conviction (Young 1967, 49-51). As a result, the patent medicine and proprietary nostrum industry—the industry whose products provoked widespread consumer interest in favor of food and drugs regulation in the first placewas never successfully regulated. The fly-by-night nature of much of the nostrum industry, combined with the fact it was extremely difficult for the Bureau to uphold its rulings in court, meant that the agency was generally ineffective in controlling misleading therapeutic claims (Young 1967, 60-65). Accordingly, while consumers benefited from enforcement of the Pure Food and Drugs Act, they did not benefit in the way that they had originally anticipated — through improved information about drug quality and safety.

\section{Conclusion}

We explore the origins and effects of the Pure Food and Drugs Act of 1906. Both the narrative and statistical evidence suggest that a nuanced combination of the three

\footnotetext{
${ }^{9}$ It is also noteworthy that those industry groups that benefited from the Bureau's expertise were different from those groups that anticipated that the Pure Food and Drug
} 
main views of Progressive Era reform (regulatory capture, public interest, rent-seeking by bureaucrats and the press) explains the adoption of the law. Regulation was sought by specific producer, consumer, and bureaucratic interests to advance their private goals. Because their objectives conflicted a political stalemate ensued. The muckraking press eventually galvanized widespread consumer interest in food and drugs regulation and broke the impasse, allowing the law to be finally enacted.

Even so, without examination of enforcement, it is impossible to know whether these interest groups obtained the benefits of regulation that they anticipated. If not, the impact of regulation may fail to conform neatly to the predictions of any of the three theories of regulation. Because those producer interests who initially sought regulation for private gain did not shape the composition of the Bureau of Chemistry and the incentives it faced, enforcement of the Pure Food and Drugs Act did not dramatically change competitive conditions to their advantage. Similarly, because those consumer groups who lobbied for regulation did not anticipate that the Pure Food and Drugs Act would be so difficult to enforce in the courts, regulation also failed to significantly improve the quality of information about patent medicines. Hence, the "public interest" was not advanced in the market that mattered most to these consumers. Perhaps the one group that obtained lasting benefits from regulation was the Bureau of Chemistry. By successfully lobbying for legislation, Wiley secured the future of his agency. This was only a partial success, however, since, the Bureau's authority was very limited and the agency remained relatively small until the late 1930s.

Act would tilt the competitive playing field to their advantage. See Law (2004). 
The Bureau's enforcement efforts produced some gains for consumers and certain food producers, but the margins along which these gains were realized were not anticipated by those interest groups that lobbied actively on behalf of regulation in the first place. Accordingly, the history of the Pure Food and Drugs Act suggests that understanding the origins and impact of Progressive Era regulation requires not only analysis of interest group motivation, but also the organizational and institutional constraints that limit the benefits that such groups are ultimately able to obtain. 


\section{References}

Akerlof, George A. 1970. “The Market for 'Lemons': Quality Uncertainty and the Market Mechanism." Quarterly Journal of Economics 84 (August): 488-500.

Anderson, Oscar E. Jr. 1958. The Health of a Nation: Harvey W. Wiley and the Fight for Pure Food. Chicago: University of Chicago Press.

Carpenter, Daniel P. 2001. The Forging of Bureaucratic Autonomy: Reputation, Networks, and Policy Innovation in Executive Agencies, 1862-1928. Princeton: Princeton University Press.

Chalmers, David M. 1974. The Muckrake Years. New York: Van Nostrand.

Congressional Record. 1885-1906. Washington, DC: GPO

Coppin, Clayton and Jack High. 1999. The Politics of Purity: Harvey Washington Wiley and the Origins of Federal Food Policy. Ann Arbor: University of Michigan Press.

Darby, Michael R. and Edi Karni. 1973. "Free Competition and the Optimal Amount of Fraud." Journal of Law and Economics 16 (April): 67-88.

Dupré, Ruth. 1999. "If It's Yellow, It Must Be Butter: Margarine Regulation in North America Since 1886." Journal of Economic History 59 (June): 353-371.

Filler, Louis. 1976. Progressivism and Muckraking. New York: R.R. Bowker Company.

Glaeser, Edward L. and Andrei Shleifer. 2003. "The Rise of the Regulatory State." Journal of Economic Literature 41 (June): 401-25.

Goodwin, Lorine S. 1999. The Pure Food, Drug, and Drug Crusaders, 1879-1914. Jefferson: McFarland \& Company.

Hays, Samuel P. 1957. The Response to Industrialism, 1885-1914. Chicago: University of Chicago Press.

Kim, Sukkoo. 2001. "Markets and Multiunit Firms from an American Historical Perspective." Advances in Strategic Management 18: 305-26.

Kolko, Gabriel. 1963. The Triumph of Conservatism: A Reinterpretation of American History. New York. Macmillan.

Law, Marc T. 2003. "The Origins of State Pure Food Regulation.” Journal of Economic History, 63 (December): 1103-1130. 
Law, Marc T. 2004. "How Do Regulators Regulate? Enforcement of the Pure Food and Drug Act, 1907-38." Unpublished manuscript, Department of Economics, University of Vermont.

Lee, R. Alton 1973. A History of Regulatory Taxation. Lexington: University of Kentucky Press.

Libecap, Gary D. 1992. "The Rise of the Chicago Packers and the Origins of Meat Inspection and Antitrust." Economic Inquiry 30 (April): 242-262.

McCluskey, Jill J. 2000. "A Game Theoretic Approach to Organic Foods: An Analysis of Asymmetric Information and Policy." Agricultural and Resource Economics Review 29 (April):1-9.

Niskanen, William A. 1971. Bureaucracy and Representative Government. Chicago: Aldine-Atherton.

Okun, Mitchell. 1986. Fair Play in the Marketplace. Dekalb: Northern Illinois University Press.

Olmstead, Alan L. and Paul W. Rhode. 2004. " The 'Tuberculosis Cattle Trust': Disease Contagion in an Era of Regulatory Uncertainty." Journal of Economic History 64 (December): 929-63.

Olson, Mancur. 1965. The Logic of Collective Action: Public Goods and the Theory of Groups. Cambridge, MA: Harvard University Press.

Peltzman, Sam 1976. “Toward a More General Theory of Regulation.” Journal of Law and Economics 19 (August): 211-240.

Reiger, Cornelius 1932. The Era of the Muckrakers. Chapel Hill: University of North Carolina Press.

Robinson, Lisa M. 1990. "Regulating What We Eat: Mary Engle Pennington and the Food Research Laboratory.” Agricultural History 64 (April): 143-53.

Stigler, George J. 1971. "The Theory of Economic Regulation.” Bell Journal of Economics and Management Science 2 (Spring): 3-21

Strasser, Susan 1989. Satisfaction Guaranteed: The Making of the American Mass Market. New York: Pantheon Books.

U.S. Bureau of the Census. 1900. Census of Population. Washington, DC: GPO.

U.S. Bureau of the Census. 1905. Census of Manufactures. Washington, DC: GPO. 
U.S. Senate. 1899-1900. “Adulteration of Food Products.” Senate Report No. 516, $56^{\text {th }}$ Congress, $1^{\text {st }}$ Session, v. 3888.

1901-02. "Adulteration of Food Products." Senate Report No. 141, 56 Congress, $2^{\text {nd }}$ Session, v. 4038.

1902. “Adulteration of Articles of Food: A Tabulated Statement Prepared by the Agriculture Department for the Senate Committee on Manufactures Showing the Adulteration of the Most Common Articles of Food Consumed in the United States." Senate Document No. 181, $57^{\text {th }}$ Congress, $1^{\text {st }}$ Session, v. 4234.

Wood, Donna J. 1986. The Strategic Uses of Public Policy: Business and Government in the Progressive Era. Marshfield: Pitman Publishing.

Yeager, Mary A. 1981. Competition and Regulation: The Development of Oligopoly in the Meat Packing Industry. Greenwich: JAI Press.

Young, James H. 1967. The Medical Messiahs: A Social History of Quackery in Twentieth Century America. Princeton: Princeton University Press.

1989. Pure Food: Securing the Federal Food and Drugs Act of 1906. Princeton: Princeton University Press.

1992. "Food and Drug Enforcers in the 1920s: Restraining and

Educating Business." Business and Economic History 21 (June): 119-128. 
Table 1

Descriptive statistics (by state)

\begin{tabular}{lcc}
\hline Variable & Mean & Standard Deviation \\
\hline Dependent variable & & 0.46 \\
Vote in 1903 (Yes=1) & 0.32 & 0.46 \\
Vote in 1906 (Yes=1) & 0.71 & \\
Producer interest variables & & 0.84 \\
Value of patent medicine production per capita (\$) & 0.67 & 0.53 \\
Number of physicians per 1,000 in 1900 & 1.63 & 0.22 \\
Number of NFMA firms per 100,000 & 0.13 & 0.25 \\
Blended whiskey indicator (0, 1) & 0.07 & 0.30 \\
Straight whiskey indicator (0, 1) & 0.09 & 0.50 \\
Large food manufacturing indicator (0, 1) & 0.48 & \\
Consumer interest variables & & 0.20 \\
WCTU dues per 1,000 & 0.32 & 0.13 \\
Protestant index & 0.24 & \\
Other controls & & 0.48 \\
Republican indicator (in 1903) & 0.64 & 0.48 \\
Republican indicator (in 1905) & 0.63 & 0.65 \\
First dimension D-Nominate score (in 1903) & 0.18 & 0.64 \\
First dimension D-Nominate score (in 1905) & 0.21 & \\
\hline
\end{tabular}

Sources: Voting data as well as information on the number of NFMA firms in each state are from the Congressional Record (1903 and 1906). The value of patent medicine production is in dollars and is taken from U.S. Bureau of the Census (1905). The number of physicians in 1900 is from U.S. Bureau of the Census (1900). The large food manufacturing indicator variable is a binary variable that equals 1 in states that have food manufacturing firms that produce in excess of $\$ 1,000,000$ of output and 0 otherwise. Data on food manufacturing production is taken from the U.S. Bureau of the Census (1905). Blended and straight whiskey indicators are included to measure the influence of blended and straight whiskey manufacturers.

Blended whiskey and straight whiskey were produced in different states. The blended whiskey indicator is a binary that equals 1 for IL, IN, and $\mathrm{OH}$ and 0 otherwise. The straight whiskey indicator equals 1 for KT, MD, VA and PA, and 0 otherwise. First dimension D-Nominate scores are from VOTEVIEW (http://voteview.uh.edu). Lower scores indicate a more "liberal" ideology toward economic issues. The Republican Indicator is a binary variable that equals 1 if a Senator was Republican and 0 otherwise. Information on party membership was also taken from VOTEVIEW. WCTU dues per capita and the Protestant index were supplied by Tomas Nonenmacher and Lee Alston. 
Table 2

Probit regression estimates of the factors shaping Senate voting on pure food and drug regulation in 1903 and 1906

\begin{tabular}{lcc}
\hline & $(1)$ & $(2)$ \\
& Vote in 1903 & Vote in 1906 \\
& $($ Yes $=1)$ & $($ Yes $=1)$ \\
\hline Constant & -1.00 & -0.18 \\
& $(0.68)$ & $(0.76)$ \\
Value of patent medicine production per capita & $-0.73^{* *}$ & -0.20 \\
Number of physicians per 1,000 persons in 1900 & $(0.31)$ & $(0.22)$ \\
Number of NFMA firms per 100,000 persons & 0.14 & $0.63^{*}$ \\
Blended whiskey indicator & $(0.39)$ & $(0.37)$ \\
Straight whiskey indicator & 0.001 & 0.09 \\
& $(0.08)$ & $(0.09)$ \\
Large food manufacturing firm indicator & $-6.76 * * *$ & -0.26 \\
& $(0.43)$ & $(0.71)$ \\
WCTU dues per 1,000 & $2.23 * * *$ & $1.94 * * *$ \\
Protestant index & $(0.62)$ & $(0.71)$ \\
Republican indicator & 0.24 & 0.96 \\
First dimension D-Nominate score & $(0.45)$ & $(0.76)$ \\
McFadden-R ${ }^{2}$ statistic & 1.30 & $3.87 * * *$ \\
Likelihood ratio-statistic & $(0.95)$ & $(1.34)$ \\
\hline
\end{tabular}

Notes: Regressions were estimated by a probit model. Heteroskedasticity-robust standard errors are in parentheses.

* Statistically significant at the 10 percent level.

** Statistically significant at the 5 percent level.

*** Statistically significant at the 1 percent level. 
Table 3

Marginal effects of explanatory variables on Senate voting in pure food and drug regulation in 1903 and 1906

\begin{tabular}{lcc}
\hline & $(1)$ & $(2)$ \\
& Vote in 1903 & Vote in 1906 \\
\hline Value of patent medicine production per capita & -0.14 & -0.04 \\
Number of physicians per 1,000 persons in 1900 & 0.02 & -0.04 \\
Number of NFMA firms per 100,000 persons & 0.002 & 0.13 \\
Blended whiskey indicator & -0.13 & -0.02 \\
Straight whiskey indicator & 0.42 & 0.39 \\
Large food manufacturing firm indicator & 0.04 & 0.20 \\
WCTU dues per 1,000 & 0.25 & 0.77 \\
Protestant index & 0.01 & 0.16 \\
Republican indicator & 0.10 & 0.38 \\
First dimension D-Nominate score & -0.26 & -0.16 \\
\hline
\end{tabular}

Notes: These values are based on the probit regression estimates reported in Table 2 and are calculated at their mean values. 